\title{
Chemical and bioactive characterization of pot-pollen produced by Melipona and Scaptotrigona stingless bees from Paria Grande, Amazonas State, Venezuela
}

\author{
Vit Patricia ${ }^{1,2,3 *}$, Santiago Bertha ${ }^{1}$, Pedro Silvia R.M ${ }^{4}$, Javier Ruíz ${ }^{1}$, Favian Maza², Peña-Vera María ${ }^{5}$, \\ Pérez-Pérez Elizabeth ${ }^{5}$ \\ ${ }^{1}$ Food Science Departament, Faculty of Pharmacy and Bioanalysis, Universidad de Los Andes, Mérida 5101, Venezuela, ${ }^{2}$ Currently, Prometeo \\ Researcher, Faculty of Agricultural and Livestock Sciences, Universidad Técnica de Machala, Machala, El Oro, Ecuador, ${ }^{3}$ Honorary Associate \\ Biomedical Sciences, School of Medical Sciences, The University of Sydney, 75 East Street, Lidcombe, NSW 1825, Australia, ${ }^{4}$ Biology \\ Department, Faculty of Philosophy, Science and Letters, Universidade de São Paulo, Ribeirão Preto, SP, Brazil. ${ }^{5}$ Laboratory of Molecular \\ Biology, Faculty of Pharmacy and Bioanalysis, Universidad de Los Andes, Mérida 5101, Venezuela
}

\section{A B S T R A C T}

\begin{abstract}
The chemical composition and bioactivity indicators (flavonoids, polyphenols, and antioxidant activity) of bee pollen produced by two Meliponini bee genera (Melipona and Scaptotrigona) in Paria Grande, Amazonas state, Venezuela, were compared. Proximal analyses were performed in triplicate following standard methods. Moisture, ash, and crude fat were done by volumetric methods, proteins by the microKjeldahl method (digestion with sulfuric acid and catalysts, distillation of ammonia by steam with sodium hydroxide and sodium thiosulphate, collection in boric acid and titration with hydrochloric acid), and carbohydrates by difference. Bioactivity was measured by spectrophotometry: The antioxidant activity by the ABTS method, flavonoids with a modified aluminum chloride method, and polyphenols with Folin-Ciocalteu. The following compositional and bioactivity variations were observed for the contents of moisture (43.49- 48.54) g/100g pollen, ash (1.94-2.33) g/100g pollen, fat (3.19-6.72) g/100g pollen, proteins (16.80-18.32) g/100g pollen, carbohydrates (27.62-31.03) g/100g pollen, antioxidant activity $(373.5-493.6) \mu \mathrm{g}$ TEAC/100g pollen, flavonoids $(1,110.7-1,644.9)$ mg $\mathrm{QE} / 100 \mathrm{~g}$ pollen, and polyphenols $(1,576.9-3,905.6) \mathrm{mg} \mathrm{GAE} / 100 \mathrm{~g}$ pollen. This study will benefit further nutrional proposals on this proteinaceous food of bee origin, and supports Venezuelan meliponiculture in the Amazone.
\end{abstract}

Keywords: Antioxidant activity; Flavonoids; Meliponini; Proximal analysis; Pot pollen; Polyphenols

\section{INTRODUCTION}

Bee pollen -as well as honey and propolis, has been widely studied for Apis mellifera, as recently reviewed (Vit, 1999). In Venezuela the botanical origin (Barth et al., 2011) and the chemical composition of Apis mellifera pollen loads from Los Andes in Cacute (Vit et al., 2008) and Misintá (Vit and Santiago, 2008), Mérida state. Also the antioxidant activity of aqueous, ethanolic and methanolic extracts of yellow, ochre, orange and brown pollen loads was compared (Pérez-Pérez et al., 2012).

The Warime Cooperative of Paria Grande Meliponicultors in the Amazonas state, Venezuela operates since year 2005. These Piaroa or Huottuja meliponicultors -also named stingless bee keepers, harvest honey and pollen produced in cerumen pots by stingless bees (Meliponini) (Pérez and Salas, 2008) and currently is expanded to 120 producers as informed by the president Mr. Alfonso Pérez in 2013. Studies on chemical composition of pot-pollen produced by stingless bees from the genus Melipona, will support the inclusion in sanitary procedures required for controlled marketing, to support this initiative of ancestral knowledge and recovery of native Indian traditions and environmental protection. This pollen is very sour and creamy compared with dried Apis mellifera pollen loads, because Meliponini ferment their pollen inside the nest; possibly it is richer in lactic acid as we found in stingless bee pot-honey (Vit et al., 2011). Menezes et al. (2012) proposed method to collect unfermented Meliponini pollen loads to increase acceptance, because in Brazil consumers prefer unfermented pot-pollen of Scaptotrigona depilis. However,

\footnotetext{
${ }^{*}$ Corresponding author:

Vit Patricia, Food Science Department, Faculty of Pharmacy and Bioanalysis, Universidad de Los Andes, Mérida 5101, Venezuela.

E-mail: vitolivier@gmail.com 
in Venezuela sour taste of pot-pollen is highly appreciated because it reminds lemon, indeed when mixed with water it is named "pollen-lemonade".

Bee pollen is used for its nutritional value in the human diet (Ioirish, 1985; Krell, 1996). It is made up of natural flower pollen mixed with nectar and bee secretions, compacted in the corbiculae (Michener, 1999). Honey and other bee products, such as royal jelly, pollen and propolis may be used as functional foods because of their naturally high antioxidant potential (Viuda-Martos et al., 2008). Silva et al. (2006) studied the composition and free radical scavenging activities of two samples of yellow and brown pollen loads of Melipona subnitida from the Brazilian Northerneast. These authors isolated naringenin, isorhamnetin, and D-mannitol from the Mimosa gemmulata yellow pollen, and $\beta$-sitosterol, tricetin, selagin, and 8-methoxiherbacetin from the Fabaceae brown pollen. The $\mathrm{EC}_{50}$ of ethanolic extracts in yellow and brown pollen was $104.5 \pm 0.5$, and $106.1 \pm 1.3 \mu \mathrm{g} / \mathrm{mL}$. Later, Silva et al. (2009) evaluated free radical scavenging activity of ethanolic extracts of pollen loads from stingless bee Melipona rufiventris "uruçu amarela", finding a concentration of a scavenger of active oxygen species of $104.1 \pm 1.2 \mu \mathrm{g} / \mathrm{mL}$. In recent studies, Tohamy et al. (2014) investigated the anti-mutagenic, antihistopathologic and antioxidant effects of water extracts of Egyptian bee pollen (WEBP) in induced hepatic, renal, testicular and genotoxicity in male albino mice (Mus muscullus), finding that bee pollen is potent in exerting an ameliorative effect.

In Venezuela and Ecuador, bee pollen is not regulated, only honey norms for Apis mellifera are available from the Venezuelan Commission of Norms (COVENIN 1984 a,b) and the Ecuadorian Technical Norm from the Ecuadorian Institute of Normalization (NTE INEN, 1988). Besides the well known commercial pollen loads of Apis mellifera, there is another type of pollen produced in cerumen pots by stingless bees (Meliponini), this pot-pollen is produced by the Warime Cooperative of Meliponicultors in Paria Grande, and needs to be characterized. The objective of this work is to analyze the proximal content (moisture, ash, proteins and fat), and bioactivity indicators (total antioxidant activity TAA, flavonoid and polyphenol contents) of potpollen collected, processed and stored in cerumen pots by Melipona (Michmelia) sp. aff. eburnea and Scaptotrigona cf. ochrotricha stingless bees with a similar palynological origin in Paria Grande, Amazonas state, Venezuela.

\section{MATERIALS AND METHODS}

Pot-pollen samples: Approximately $100 \mathrm{~g}$ of pot-pollen produced by two stingless bee species were collected from three nests in Paria Grande, Amazonas state, Venezuela, and were kept frozen at $-20^{\circ} \mathrm{C}$ until analysis.

Botanical origin: Natural pollen analysis was done following the Louveaux et al. (Louveaux et al., 1978) method, and the frequency classification: dominant $(>45 \%)$, accessory (15\% to $45 \%)$, important isolated (3\% to $14 \%)$ and rare $(<3 \%)$. Pollen plates were used for identification (Barth, 1970; Vit, 2005).

Entomological origin: The two stingless bee species known with ethnic names "tobillo morrocoy" and "sonquette", were kept in isopropyl alcohol for further entomological identification at Universidade de São Paulo, Ribeirão Preto, Brazil, as Melipona (Michmelia) sp. aff. eburnea Friese, 1900 and Scaptotrigona cf. ochrotricha (Buysson, 1892), respectively.

Proximal analyses: Proximal analyses were done in triplicate following oficial analytical methods (AOAC, 1999). Moisture, ash and fat were done by gravimetric methods; proteins were measured by the microKjeldhal method following sulfuric acid (Merck, Darmstadt, Germany) digestion, ammonia distillation by vapor flow with sodium hydroxide (Sigma Aldrich, USA) and sodium thyosulphate (Merck, Darmstadt, Germany), collection in boric acid (Sigma Aldrich, USA) and titration with hydrochloric acid); carbohidrates were calculated by difference.

Ethanolic homogenate preparations: A weight of $100 \pm 10 \mathrm{mg}$ of each pot-pollen type was placed on a glass homogenizer (Thomas No. A3528, USA), and $5 \mathrm{~mL}$ of ethanol 95\% (v/v) (Riedel de Haën, Europe) were added, and homogenized on an ice bath. Homogenates were centrifuged in a BHG Optima II (USA) centrifuge at 3,000 rpm for $10 \mathrm{~min}$, and supernatants were used for biochemical analysis (Pérez-Pérez et al., 2012).

Total antioxidant activity by the ABTS method: For the method of ethanolic decolorization of ABTS solution (Sigma, Canada), ABTS was dissolved in water to a $7 \mathrm{mM}$ concentration. ABTS radical cation $\left(\mathrm{ABTS}^{+*}\right)$ was produced by reacting $7 \mathrm{mM}$ stock solution with potassium persulfate (Merck, Darmstadt, Germany) to a final concentration of $2.45 \mathrm{mM}$ (in water), in the dark at room temperature (RT) for 12-16 h before use (Re et al., 1999) [43]. For this pollen analysis, the $\mathrm{ABTS}^{+\cdot}$ solution was diluted with $20 \%$ ethanol (v/v) up to $0.60-0.70$ absorbance units at $735 \mathrm{~nm}, 100 \mu \mathrm{L}$ of homogenates were diluted in ethanol, and mixed with $7.5 \mathrm{~mL}$ of $\mathrm{ABTS}^{+\bullet}$ solution diluted in ethanol $20 \%(\mathrm{v} / \mathrm{v})$. Absorbance values were measured 6 min after mixture. A solution of $8 \mathrm{mM}$ Trolox (Sigma, Steinheim, Germany) was used as antioxidant standard. Trolox was diluted to obtain 1, 2, 4 and $8 \mu \mathrm{M}$ in $5 \mathrm{mM}$ PBS buffer ( $\mathrm{pH}$ 7.4). Decolorization percentages at $734 \mathrm{~nm}$ after $6 \mathrm{~min}$ were 
calculated and plotted as a function of different Trolox concentrations, and TAA was reported accordingly. TAA value for pollen is equivalent to Trolox concentration that produces the same decolorization percentage. Purified antioxidants like quercetin, melatonin and lipoic acid were used as controls of the antioxidant activity. Results are expressed as $\mu \mathrm{g}$ Trolox equivalents (TEAC) per $100 \mathrm{~g}$ honey.

Flavonoid content: Flavonoid content was measured using a modification of the aluminum chloride method (Woisky and Salatino, 1998). The flavonoid concentration was measured with a calibration curve using standard solutions of quercetin (Sigma, Steinheim, Germany) diluted up to 25, 50 and $100 \mu \mathrm{g} / \mathrm{mL}$ in ethanol $80 \%$ (v/v). Standard solutions $(0.5 \mathrm{~mL})$ were mixed with $1.5 \mathrm{~mL} \mathrm{95 \% (v/v)}$ ethanol, $0.1 \mathrm{~mL}$ of aluminum chloride (Fisher Scientific, New Jersey, USA) $10 \%(\mathrm{w} / \mathrm{v}), 0.1 \mathrm{~mL}$ of potassium acetate (Sigma Aldrich, USA) $1 \mathrm{M}$ and $2.8 \mathrm{~mL}$ of distilled water. After incubation at ambient temperature for $30 \mathrm{~min}$, absorbance was recorded at $415 \mathrm{~nm}$. In a similar way, $0.5 \mathrm{~mL}$ of ethanolic extracts of pollen homogenates reacted with aluminum chloride for flavonoid content determinations. Results are expressed as mg quercetin equivalents (QE) per $100 \mathrm{~g}$ honey.

Polyphenol content: Polyphenol content was analyzed by spectrometry at $765 \mathrm{~nm}$ using Folin-Ciocalteu (Sigma-Aldrich, St. Louis, USA) reagent (Singleton, 1999). One hundred microliters of pollen homogenates were mixed with $500 \mu \mathrm{L}$ of Folin-Ciocalteu's reagent diluted $1 / 10$ with water, to which $400 \mu \mathrm{L}$ of sodium carbonate was added (Sigma, Steinheim, Germany) 7.5\% (w/v). Absorbance at $765 \mathrm{~nm}$ was recorded after $10 \mathrm{~min}$ of reaction at $37^{\circ} \mathrm{C}$, against a blank with MQ water instead of ethanolic extract. The polyphenol concentration was estimated with a calibration curve using a solution of $0.1 \mathrm{~g} / \mathrm{L}$ of gallic acid (Sigma, Steinheim, Germany) as standard $(0,0.25,0.05$ and $0.1 \mathrm{~g} / \mathrm{L})$. Results are expressed as $\mathrm{mg}$ equivalents of gallic acid (GAE) per $100 \mathrm{~g}$ honey.

\section{Statistical analysis}

All experiments were done in triplicate. Data were analyzed by ANOVA $(\mathrm{P}<0.05)$, with average comparison through post hoc Scheffé test using SPSS 12.0 software (SPSS, 2004) to compare variations of physicochemical composition and bioactivity in the two pollen types with different entomological origin (Melipona sp. and Scaptotrigona sp.). Media \pm SD are given for each parameter.

\section{RESULTS}

The pot-pollen produced by two species of Melipona aff. eburnea and Scaptotrigona cf. ochrotricha had two dominant pollen types; one of the Fabaceae Papilionoideae family 46\% in the Melipona, and 20\% in the Scaptotrigona pot-pollen, and the other of the Malpighiaceae family that was found as less frequent accessory pollen 26\% in Melipona, but dominant with $54 \%$ in Scaptotrigona pot-pollen. Other pollen types from Apocinaceae, Arecaceae, Bixaceae, Euphorbiaceae, Fabaceae Mimosoideae, Lamiaceae, Malvaceae, Myrtaceae, and Poaceae families were also detected with frequencies lower than $3 \%$.

The chemical composition of pot-pollen produced by Melipona and Scaptotrigona bees from Paria Grande, were done by proximal analysis moisture, ash, fat, protein and carbohydrate contents is given in Table 1.

In Table 2 is presented data on total antioxidant activity (TAA), flavonoid and polyphenol contents of ethanolic homogenates of Melipona and Scaptotrigona pot-pollen, besides the total antioxidant activity of purified antioxidants like quercetin, melatonin and lipoic acid used as controls of the antioxidant activity.

\section{DISCUSSION}

Stingless bee origin is estimated in the late Cretaceous (Engel and Michener, 2013), and since then also their interactions with plants (Lunau, 2004). Bees forage plants based on a cost-benefit balance. Besides floral attractiveness to a particular stingless bee species, other factors determine pollen choices and rate of visitation: 1. Presence of competitors, 2. Distance from the nest to the resources, 3. Bee communication strategy, 4 . Number of bees in the nest, 5. Type of soil, 6. Temperature, 7. Light (Kajobe, 2007; Corbet et al., 2008).

The dominant pollen types were from the family Fabaceae Papilionoideae (46\%) Melipona, and Malpighiaceae (54\%) Scaptotrigona pot-pollen. The higher fat content of Scaptotrigona pollen could be explained by the oil glands of Malpighiaceae. Although most genera of Malpighiaceae are generally pollinated by oil collecting bees like the Centridini group (Rego et al., 2006). Novais and Absy (2013) studied pollen pots of Amazonian Tetragonisca angustula in Belterra and Santarém, Pará, Brazil found that Byrsonima, Cecropia, Clidemia hirta, Davilla kunthii, Eriope, Myrcia and Vismia guianensis were the most significant pollen types with frequencies above $70 \%$. Absy et al. (1984) recommend that plants of identified pollen sources should be cultivated near to meliponaries to support stingless beekeeping as potentially sustainable economic activity. Particularly, planting native species of the genera Astrocaryum, Bactris, Byrsonima, Citharexylum, Couma, Euterpe, and Vitex, is adviced to facilitate beekeeping especially in seasons of pollen 
Vit, et al.: Chemical and bioactive analysis of pot-pollen

Table 1: Proximal analysis of pot-pollen from Melipona sp. and Scaptotrigona sp.

\begin{tabular}{|c|c|c|c|c|c|c|}
\hline $\begin{array}{l}\text { Pollen type } \\
\text { "ethnic name" Bee species }\end{array}$ & $\mathrm{n}$ & $\begin{array}{l}\text { Moisture } \\
(\mathrm{g} / 100 \mathrm{~g})\end{array}$ & $\begin{array}{c}\text { Ash } \\
(\mathrm{g} / 100 \mathrm{~g})\end{array}$ & $\begin{array}{c}\text { Fat } \\
(\mathrm{g} / 100 \mathrm{~g})\end{array}$ & $\begin{array}{l}\text { Proteins } \\
(\mathrm{g} / 100 \mathrm{~g})\end{array}$ & $\begin{array}{l}\text { Carbohidrates } \\
(\mathrm{g} / 100 \mathrm{~g})\end{array}$ \\
\hline $\begin{array}{l}\text { "Tobillo morrocoy" } \\
\text { Melipona sp. aff. eburnea }\end{array}$ & 3 & $48.54 \pm 0.41^{b}$ & $2.33 \pm 0.10^{b}$ & $3.19 \pm 0.11^{a}$ & $18.32 \pm 0.10^{b}$ & $27.62 \pm 0.50^{\mathrm{a}}$ \\
\hline $\begin{array}{l}\text { "Sonquette" } \\
\text { Scaptotrigona sp. cf. ochrotricha }\end{array}$ & 3 & $43.49 \pm 0.95^{a}$ & $1.94 \pm 0.35^{a}$ & $6.72 \pm 0.58^{b}$ & $16.80 \pm 0.21^{a}$ & $31.03 \pm 1.08^{b}$ \\
\hline
\end{tabular}

Table 2: Bioactivity properties of Melipona and Scaptotrigona pot-pollen ethanolic homogenates

\begin{tabular}{lcccc}
$\begin{array}{l}\text { Pollen type } \\
\text { "ethnic name" Bee species }\end{array}$ & $\mathrm{n}$ & $\begin{array}{c}\text { Total antioxidant activity } \\
\text { (TEAC/100 g pollen) }\end{array}$ & $\begin{array}{c}\text { Flavonoid content } \\
\text { (mg of QE/100 g pollen) }\end{array}$ & $\begin{array}{c}\text { Polyphenol content } \\
\text { (mg GAE/100 g pollen) }\end{array}$ \\
$\begin{array}{l}\text { "Tobillo morrocoy" } \\
\begin{array}{l}\text { Melipona sp. aff. eburnea } \\
\text { "Sonquette" }\end{array}\end{array}$ & 3 & $373.5 \pm 21.0^{\mathrm{d}}$ & $1,576.9 \pm 35.8^{\mathrm{a}}$ & $3,905.6 \pm 64.0^{\mathrm{b}}$ \\
Scaptotrigona sp. cf. ochrotricha & 3 & $493.6 \pm 2.0^{\mathrm{e}}$ & $1,110.7 \pm 66.8^{\mathrm{a}}$ & $1,644.9 \pm 16.0^{\mathrm{b}}$ \\
Quercetin & & $130.4 \pm 12.5^{\mathrm{c}}$ & \\
$\quad$ Melatonin & & $112.7 \pm 8.7^{\mathrm{b}}$ & \\
Lipoic acid & $67.8 \pm 2.4^{\mathrm{a}}$ & & \\
\hline
\end{tabular}

scarcity; and considering that with the pollination service of the bees, local food production may also increase (Rech and Absy, 2011). These authors reported Scaptotrigona sp. pot-pollen with three secondary pollen types from two species of the family Fabaceae Papilionoideae: Aldina latifolia (24.2\%), Swartzia dolichopoda (30.8\%), and Vitex cymosa Lamiaceae (34.5\%)

The botanical origin of the genus Byrsonima (Malpighiaceae) found here as a less frequent source in the Melipona and Scaptotrigona pot-pollen was also reported for Centris (Ribeiro et al., 2008) and Cephalotrigona femorata with a secondary frequency of $33.4 \%$ (Absy et al., 1984). The Malpighiaceae family offers oil from elaiophore calyx glands to pollinators (Pedro, 1994). However, pollination by pollen-collecting bees has probably shifted to remove their calyx glands in a group of the over 950 species of Malpighiaceae in the New World, after an almost obligate relationship of very specialized pollinators that explain the floral conservatism of Neotropical Malpighiaceae (Anderson, 1979).

The following compositional variations were observed in Table 1 for the contents of moisture (43.49 - 48.54) g/100g pollen, ash (1.94-2.33) g/100g pollen, fat (3.19-6.72) g/100g pollen, proteins (16.8018.32) g/100g pollen and carbohidrates (27.62-31.03) $\mathrm{g} / 100 \mathrm{~g}$ pollen. The pollen collected by Scaptotrigona was $5 \%$ drier and had almost double fat content than that of Melipona. These differences, besides the $1.5 \%$ higher protein content of Melipona pollen, caused its lower carbohydrate content, almost 4\% compared with the Scaptotrigona pollen. Compared to Apis mellifera fresh pollen from Cacute (Vit et al., 2008) and Misintá (Vit and Santiago, 2008), Venezuela; pot-pollen from the two Meliponini species investigated here showed a higher moisture than 13.24-17.93 \%, higher fat than (1.73-5.37\%), lower proteins than (24.17-52.56\%), and similar ash content (1.60-2.18\%).
The TAA of ethanol extracts of pot-pollen from Melipona was lower than that of Scaptotrigona (Table 2). Similarly, lower values of polyphenol contents were also observed in the Melipona pot-pollen, compared to Scaptotrigona potpollen. There is a positive relation between polyphenol content and antioxidant activity (TAA values), but not with the flavonoid content, as previously informed in another research for unifloral honey (Vit et al., 2010). Freire et al. (2012) determined phenolic and flavonoid contents, and antioxidant properties of twenty-five bee pollen harvested during a nine-month period from the Canavieiras municipality (Northeastern Brazil). The total phenolic contents ranged from 41.5 to $213.2 \mathrm{mg}$ GAE/g, and antioxidant activities based on the (ABTS) correlated with the total phenolic contents. Morais et al. (2011) determined phenolic content and antioxidant properties of pollen from five Portuguese Natural-Parks such as Parque Nacional Peneda Gerês (PNPG); Parque Natural do Montesinho (PNM); Parque Natural do Alvão (PNA); Parque Natural da Serra da Estrela (PNSE) and Parque Natural do Douro Internacional (PNDI). The phenolic contents, determined 10.5 and $16.8 \mathrm{mg}$ GAE/g of extract, in bee pollen from PNM and PNDI, respectively. The free radical scavenging measured showed the highest effective extract - PNM with $\mathrm{EC}_{50} 2.16$, followed by PND with $2.24 \mathrm{mg} / \mathrm{mL}$.

Several methods for determining the antioxidant activity in honey have been used, and among them the ABTS assay is referred to by many authors. This assay assesses the total radical scavenging capacity based on the ability of a compound to scavenge the stable ABTS radical cation $\left(\right.$ ABTS $^{*+}$ ) (Suarez-Alvarez et al., 2009). Besides to the simplicity of this assay, there is little correlation between the TEAC value and the number of electrons an antioxidant can give away. In spite of this, the ABTS assay is considered an easy and accurate method for use in the antioxidant capacity studies in honey because it allows 
to determine the radical scavenging ability present in the honey by the hydrogen-donation reaction. On the other side, honey phytochemicals are mainly represented by the extensive class of phenolic compounds, being the major class the flavonoids (flavonols, flavanols and flavones), followed by phenolic acids (benzoic acids, phenylacetic and hydroxycinnamic acids). In pollen samples, the highest quantity of flavonoids exists like glycosides, namely aglycones, being quercetin the majoritarian compound (Bogdanov, 2011).

It has been widely demonstrated that flavonoids are very effective as scavengers of reactive oxygen species (ROS): peroxide, hydroxyl and superoxide radicals, as well as against reactive nitrogen species (RNS) like nitric oxide and peroxyl nitrite (Yen and Lai, 2003). Moreover, flavonoids have high affinity for proteins and other biological macromolecules, such as hormones and nucleic acids, and for divalent ions of metals; and also have high catalytic ability for the electron transfer and act as radical scavengers. Flavonoids are capable as act like antioxidants because have substituents with a high capacity of donate hydrogen/electrons with adequate reduction potentials; and the ability to relocate the resulting radical (Rivas-Gonzalo and García-Alonso, 2002). It has been described some structural criteria necessary for effectiveness in capturing radicals of flavonoid molecules, through ABTS radical cation assay, among them: (i) the presence of the structure 3',4'-o-dihydroxy on B aromatic ring (catechol), which gives greater stability to the formed radical; (ii) the existence of hydroxyl groups on carbons 5 and 7 of A ring; (iii) the double bond located at position 2,3 in conjunction with the 4-oxo and 3-hydroxy on $\mathrm{C}$ ring, responsible for the relocation from the $\mathrm{B}$ ring (the peroxyl radicals produced are stabilized by the resonance effect of the aromatic nuclei); and (iv) the appearance of the hydroxyl groups in position 3 and 5 with 4-oxo function in rings $\mathrm{A}$ and $\mathrm{C}$, and with 2,3 double bond between positions generate the maximum potential free radical scavenger (Burda and Oleszek, 2001; Heim et al., 2001; Rivas-Gonzalo and García-Alonso, 2002). Depending of its structure, the antioxidant activity of some flavonoids present in pollen samples cannot be determined by ABTS assay because the mechanism involved is not electron/hydrogen transfer, the principal mechanism evaluated in this method.

More recently, Pascoal et al. (2014) evaluated the biological activities of eight commercial bee pollens purchased from the market. Phenolic contents varied from 32.15 to 18.55 GAE/g, flavonoids varied from 10.14 to $3.92 \mathrm{QE} / \mathrm{g}$. All the samples exhibited antimutagenic and antimicrobial activity, being Staphylococcus aureus the most sensitive and Candida glabrata the most resistant of the microorganisms studied. These authors observed positive correlations between polyphenols, flavonoids, antioxidant activity and antimicrobial activity of Apis mellifera bee pollen. These are few evidences about the antioxidant activity of honey, pollen and propolis and its relationship with total polyphenol content, and especially flavonoid concentration.

There is no statistical data available for the bee industry in Venezuela, and this lack of organization is reflected in the low participation in international debates on biodiversity protection of feral bees endangered of extinction (Bouga, 2013), contamination of bee products with genetically modified organisma (GMO) and its residues (Haefeker, 2013), or the effects of pesticides in honeybee and authenticity of honey (Maxwell, 2013), as recently discussed in round tables of the APIMONDIA XXXXIII International Congress of Apiculture held in Kiev, Ucrania from the $2^{\text {th }}$ September to the $4^{\text {th }}$. October 2013.

The fact that pollen regulations still need to be created in Venezuela, offers the advantage to suggest the inclusion of pot-pollen produced by Meliponini bees different from Apis mellifera, like Melipona and Scaptotrigona. Expanded quality criteria (microbiological, contaminants, trace elements, vitamins) recommended in the review for dried Apis mellifera pollen pellets (Campos et al., 2008) could also be adopted for fresh bee pollen; in their draft these authors suggested maximum moistures of 6-8 g/100, maximum ash of $6 \mathrm{~g} / 100$, minimum protein of $15 \mathrm{~g} / 100$, minimum fat of $1.5 \mathrm{~g} / 100 \mathrm{~g}$, and instead of carbohydrates measured by difference, a minimum of total sugars $40 \mathrm{~g} / 100 \mathrm{~g}$.

\section{CONCLUSIONS}

In the current research moisture and ash contents measured with gravimetric methods, proteins (micro Kjeldahl), ether extract (Soxhlet), and bioactivity indicators measured by spectrophotometric methods to evaluate total antioxidant activity as free radical scavengers, flavonoid and polyphenol contents were compared in pot-pollen produced by Melipona (Michmelia) sp. aff. eburnea Friese, 1900 and Scaptotrigona cf. ochrotricha (Buysson, 1892) in Paria Grande, Amazonas state, Venezuela. The characterization is useful for a pot-pollen regulation database, and also as a basis for pharmaceutical studies.

The proximal composition and bioactivity of bee pollen produced by two species of stingless bees in Paria Grande, Amazonas state, Venezuela let the following observations: 1. Pot-pollen is a rich source of oligoelements in the diet given the high ash content measured in this study, 2. The pollen spectra varied according to the stingless bee species, 3. Fat content of pollen varied according to the stingless bee species and the plant they visited foraging pollen. 
To our knowledge, this is the first report on the biological activities of Venezuelan stingless bee pot-pollen, and there is very small quantity of evidence of antioxidant activity on stingless bee pollen (Silva et al., 2006; Silva et al., 2009). Our data suggest that the ethanol extract of pot-pollen have a potent antioxidant activity, similar or higher than that found for purified antioxidants like quercetin, melatonin and lipoic acid, probably due to its polyphenol content and fermentive process. This is very important to support the use of pollen as a very energetic nutritional supplement since ancient times.

\section{ACKNOWLEDGMENTS}

To Consejo de Desarrollo Científico, Humanístico, Tecnológico y del Arte from Universidad de Los Andes CDCHTA-ULA, Mérida, Venezuela for the financial support received for the project FA-530-13-08-B, for this research, and the presentation of proximal analysis data in the AsoVAC Convention, Food Technology session, held in Valencia, Venezuela, $15^{\text {th }}$ November 2013. To PrometeoSenescyt for the grant to P Vit. To Professor Favián Maza, from the Planning Department at Universidad Técnica de Machala, for his support as Institutional Prometeo to continue this research in Ecuador. To Dr. Ortrud Monika Barth from the Instituto Oswaldo Cruz, FIOCRUZ, Rio de Janeiro, Brazil for her appreciated comments on the manuscript. Mr. Alfonso Pérez, President of the Warime Cooperative of Meliponicultors from Paria Grande, Paria Grande, Amazonas State, Venezuela, made possible the pot-pollen sampling in his stingless bee hives.

\section{Author contributions}

V. P. wrote the project, collected and distributed the potpollen, S.B. and J.R. did the physicochemical analysis, P. S. R. M. did the entomological identifications, F.M. supervised the Prometeo Project, P.-P. E. supervised the antioxidant, flavonoid and polyphenol measurements of her student P.V. M. Statistics were done by V. P. and P.-P. E. All authors wrote, read and approved the final manuscript.

\section{REFERENCES}

Absy, M. L., J. M. F. Camargo, W. E. Kerr and I. P. A. Miranda. 1984. Espécies de plantas visitadas por Meliponinae (Hymenoptera, Apoidea), para coleta de pólen na região do médio Amazonas. Rev. Bras. Biol. 44: 227-237.

Alvarez-Suarez, J. M., F. Giampieri and M. Battino. 2013. Honey as a source of dietary antioxidants: Structures, bioavailability and evidence of protective effects against human chronic diseases. Curr. Med. Chem. 20: 621-638.

Anderson, W. R. 1979. Floral conservatism in neotropical malpighiaceae. Biotropica. 47: 209-223.

AOAC. 1999. Official Methods of Analysis. $15^{\text {th }}$ ed. Association of
Official Analytical Chemists, Arlington, VA, USA.

Barth, O. M. 1970. O Polen no Mel Brasileiro. Editorial Instituto Oswaldo Cruz. Rio de Janeiro, Brasil.

Barth, O. M., A. S. Freitas, E. Oliveira Sales and P. Vit. 2011. Palynological evaluation of bee pollen load batches from the Venezuelan Andes of Misintá. Interciencia. 3: 296-299.

Bogdanov, S. 2011. In: The Bee Pollen Book. Bee Product Science, Bulgaria. p1-13.

Bouga, M. 2013. Conservation of endangered diversity of bee populations. In: Proceedings of the $43^{\text {rd }}$ International Apicultural Congress. Beyond the Hive: Beekeeping and Global Challenges. Publisher Apimondia, Ukraine. p. 58.

Burda, S. and W. Oleszek. 2001. Antioxidant and antiradical activities of flavonoids. J. Agric. Food Chem. 49: 2774-2779.

Campos, M. G. R., S. Bogdanov, L. Bicudo de Almeida-Muradian, T. Szczesna, Y. Mancebo, C. Frigerio and F. Ferreira. 2008. Pollen composition and standardisation of analytical methods. JAR. 47: 154-161.

Corbet, S. A., M. Fussel, R. Ake, A. Fraser, C. Gunson, A. Savage and K. Smith. 2008. Temperature and the pollinating activity of social bees. Ecol. Entomol. 18: 17-30.

Covenin. 1984a. Miel de Abejas. Métodos de Ensayo. Covenin 2136-84. Comisión Venezolana de Normas Industriales. Fondonorma, Caracas, Venezuela.

Covenin. 1984b. Miel de Abejas. Requisitos. Covenin 2194-84. Comisión Venezolana de Normas Industriales. Fondonorma, Caracas, Venezuela.

Engel, M. S. and C. D. Michener. 2013. Geological history of the stingless bees (Apidae: Meliponini). In: Vit, P. and D. W. Roubik, (Eds.), Stingless Bees Process Honey and Pollen in Cerumen Pots. Facultad de Farmacia y Bioanálisis, Universidad de Los Andes. Mérida. Available from: http://www.saber.ula.ve/ handle/123456789/35292.

Freire, K., A. Lins, M. Dórea, F. Santos, N. Camara and T. Silva. 2012. Palynological origin, phenolic content, and antioxidant properties of honeybee-collected pollen from Bahia, Brazil. Molecules. 17: 1652-1664.

Haefeker, W. 2013. GMOs and impact on the beekeeping sector. In: Proceedings of the $43^{\text {rd }}$ International Apicultural Congress. Beyond the Hive: Beekeeping and Global Challenges. Publisher Apimondia, Ukraine. p. 59.

Hatjina, F. 2013. Bees and pesticides. In: proceedings of the $43^{\text {rd }}$ International Apicultural Congress. Beyond the Hive: Beekeeping and Global Challenges. Publisher Apimondia, Ukraine. p. 60.

Heim, K. E., A. R. Tagliaferro and D. J. Bobilya. 2002. Flavonoid antioxidants: chemistry, metabolism and structure-activity relationships. J. Nutr. Biochem. 13: 572-584.

loirish, N. 1985. Las Abejas, Farmacéuticas Aladas. Editorial Mir, Moscú.

Kajobe, R. 2007. Pollen Foraging by Apis mellifera and stingless bees Meliponula nebulate in Bwindi Impenetrable National Park, Uganda. Afr. J. Ecol. 45: 268-274.

Krell, R. 1996. Value-Added Products from Beekeeping. Food and Agriculture Organization of the United Nations, Rome.

Louveaux, J., A. Maurizio and G. Vorwohl. 1978. Methods of melissopalynology. Bee World. 59: 139-157.

Lunau, K. 2004. Adaptive radiation and coevolution - Pollination biology case studies. Organ. Divers. Evol. 4: 207-224.

Maxwell, M. 2013. Honey adulteration. In: Proceedings of the $43^{\text {rd }}$ International Apicultural Congress. Beyond the Hive: Beekeeping 
and Global Challenges. Publisher Apimondia, Ukraine. p. 61.

Menezes, C., A. Vollet Neto and V.L. Imperatriz Fonseca. 2012. A method for harvesting unfermented pollen from stingless bees (Hymenoptera, Apidae, Meliponini). JAR. 51: 240-244.

Michener, C. D. 1999. The corbiculae of bees. Apidologie. 30: 67-74.

Morais, M., L. Moreira, X. Feás and L. M. Estevinho. 2011. Honeybee-collected pollen from five Portuguese Natural Parks: Palynological origin, phenolic content, antioxidant properties and antimicrobial activity. Food Chem. Toxicol. 49: 1096-1101.

Novais, J. S. and M. Absy. 2013. Palynological examination of the pollen pots of native stingless bees from the lower Amazon region in Pará, Brazil. Palynology. 37: 218-230.

NTE INEN. 1988. Miel de Abejas. Requisitos. NTE INEN 1572. Norma Técnica Ecuatoriana. Instituto de Normalización Ecuatoriano, Quito, Ecuador.

Pascoal, A., S. Rodrigues, A. Teixeira, X. Feás and L. M. Estevinho. 2014. Biological activities of commercial bee pollens: Antimicrobial, antimutagenic, antioxidant and anti-inflammatory. Food Chem. Toxicol. 63: 233-239.

Pedro, S. M. R. 1994. Interações entre abelhas e flores em uma área de cerrado no NE do Estado de São Paulo: Abelhas coletoras de óleo (Hymenoptera: Apoidea: Apidae). In: Zucchi, R., P. M. Drumond, P. G. Fernandes da Silva, S. C. Augusto, (Eds.), Anais do I Encontro Sobre Abelhas. Universidade de São Paulo, Ribeirão Preto. Pp. 243-255.

Pérez, A. and E. Salas. 2008. Meliponicultura en Paria Grande, Estado Amazonas. In: Vit. P, (Ed.), Abejas sin aguijón y Valorización Sensorial de su Miel. APIBA, Facultad de Farmacia y Bioanálisis, Dirección General de Cultura y Extensión, Universidad de Los Andes, Mérida. p. 42.

Pérez-Pérez, E., P. Vit, E. Rivas, R. Sciortino, A. Sosa, D. Tejada and A. Rodríguez-Malaver. 2012. Antioxidant activity of four color fractions of bee pollen from Mérida, Venezuela. ALAN. 62: 375-380.

Re, R., N. Pellegrini, A. Proteggente, A. Pannala, M. Yang and C. Rice-Evans. 1999. Antioxidant activity in improved ABTS radical cation decolorization assay. Free Rad. Biol. Med. 26: 1231-1237.

Rech, A. R. and M. L. Absy. 2011. Pollen sources used by species of Meliponini (Hymenoptera: Apidae) along the Rio Negro channel in Amazonas, Brazil. Grana. 50: 150-161.

Rego, M. M. C., P. M. C. Albuquerque, M. C. Ramos and L. M. Carreira. 2006. Aspectos da biología de nidificaçao de Centris flavifrons (Friese) (Hymenoptera: Apidae, Centridini), um dos principais polinizadores do murici (Byrsonima crassifolia L. Kunth, Malpighiaceae), no Maranhão. Neotrop. Entomol. 35: 579-587.

Ribeiro, E. K. M. D., M. M. C. Rêgo and I. C. Machado. 2008. Cargas polínicas de abelhas polinizadoras de Byrsonima chrysophylla Kunth. (Malpighiaceae): fidelidade e fontes alternativas de recursos florais. Acta Bot. Bras. 22: 165-171.
Rivas-Gonzalo, J. C. and M. García-Alonso. 2002. Flavonoides en alimentos vegetales: Estructura y actividad antioxidante. Alim. Nutr. Salud. 9: 31-38.

Silva, T. M. S., C. A. Camara, A. C. S. Lins, M. Agra, E. M. S. Silva, I. Reis and B. M. Freitas. 2009. Chemical composition, botanical evaluation and screening of radical scavenging activity of collected pollen by the stingless bees Melipona rufiventris (uruçu-amarela). Ann. Acad. Bras. Ciên. 81: 173-178.

Silva, T. M. S., C. A. Camara, A. C. S. Lins, J. M. Barbosa-Filho, E. M. S. Silva, B. M. Freitas and F. A. R. Santos. 2006. Chemical composition and free radical scavenging activity of pollen loads from stingless bee Melipona subnitida Ducke. J. Food Comp. Anal. 19: 507-511.

Singleton, V. L., R. Orthofer and R. M. Lamuela-Raventos. 1999. Analysis of total phenols and other oxidation substrates and antioxidants by means of Folin-Ciocalteu reagent. Methods. Enzymol. 299: 152-178.

SPSS for Windows. 2004. Base System User's Guide, Release 12.0. SPSS Inc., Chicago.

Tohamy, A. A., E. M. Abdella, R. R. Ahmed and Y. K. Ahmed. 2014. Assessment of anti-mutagenic, anti-histopathologic and antioxidant capacities of Egyptian bee pollen and propolis extracts. Cytotechnology. 66: 283-297.

Vit, P. 2005. Melissopalynology, Venezuela. APIBA-CDCHT, Universidad de Los Andes, Mérida.

Vit, P. 2009. Origen botánico y propiedades medicinales del polen apícola. Rev. Med. Ext. Portuguesa ULA. 3: 27-34.

Vit, P., P. Herrera, D. Rodríguez and J. Carmona. 2008. Caracterización de polen apícola fresco recolectado en Cacute, en los Andes venezolanos. Rev. Inst. Nac. Hig. Rafael Rangel. 39: 7-11.

Vit, P., A. Rodríguez-Malaver, C. Rondón, I. González, M. Y. García and M. L. Di Bernardo. 2010. Bioactive indicators related to bioelements of eight unifloral honeys. ALAN. 60: 405-410.

Vit, P., L. B. Rojas, A. Usubillaga, R. Aparicio and G. Meccia, M. A. Fernando Muiño and M. T. Sancho. 2011. Presencia de ácido láctico y otros compuestos semivolátiles en mieles de Meliponini. Rev. Inst. Nac. Hig. Rafael Rangel. 42: 58-63.

Vit, P. and B. Santiago. 2008. Composición química de polen apícola fresco recolectado en el páramo de Misintá de Los Andes venezolanos. ALAN. 58: 411-415.

Viuda-Martos, M., Y. Ruíz-Navajas, J. Fernández-López and J. A. Pérez-Alvarez. 2008. Functional properties of honey, propolis, and royal jelly. J. Food Sci. 73: R117-R124.

Woisky, R. G. and A. Salatino. 1998. Analysis of propolis: Some parameters and procedures for chemical quality control. JAR. 37: 99-105.

Yen, G. C. and H. H. Lai. 2003. Inhibition of reactive nitrogen species effects in vitro and in vivo by isoflavones and soy-based food extracts. J. Agric. Food Chem. 51: 7892-7900. 